\title{
Natural and anthropogenic factors shape metazoan parasite community structure in mummichog (Fundulus heteroclitus) from two estuaries in New Brunswick, Canada
}

\author{
Christopher A. Blanar ${ }^{1}$, David J. Marcogliese ${ }^{1}$ and Catherine M. Couillard $^{2}$
}

\author{
${ }^{1}$ Fluvial Ecosystem Research Section, Aquatic Ecosystem Protection Research Division, Water Science and Technology \\ Directorate, Science and Technology Branch, Saint Lawrence Centre, Environment Canada, 105 McGill, 7th floor, Montréal, \\ Québec H2Y 2E7, Canada; \\ ${ }^{2}$ Fisheries and Oceans Canada, Maurice Lamontagne Institute, P.O. Box 1000, Mont-Joli, Québec G5H 3Z4, Canada
}

\begin{abstract}
Previously published multidisciplinary studies in the Miramichi and Bouctouche rivers (New Brunswick, Canada) noted significant changes in fish health parameters, including elevated tissue levels of organic contaminants and a wide range of physiological disturbances, in mummichog Fundulus heteroclitus (L.) from a site on the Miramichi River that received bleached kraft pulpmill and municipal effluent. The present study reports differences in the abundance of individual parasite species, as well as parasite infracommunity and component community composition, in mummichog from both rivers. These differences were evaluated in relation to host (size, condition, immune function, tissue organochlorine contaminant levels) and environmental (faecal coliform counts, salinity, temperature) data derived from the previously published studies. Overall, 18 parasite species were identified, the most common of which were Ascocotyle sp. larv., Ornithodiplostomum sp. larv., Posthodiplostomum sp. larv., and Proteocephalus filicollis (Rudolphi, 1802). There were broad differences in parasite community structure and composition between rivers and within rivers, the most prominent pattern being a pronounced difference between sites in the upper and lower estuary of each river that was likely driven by salinity. Mean infracommunity richness was also positively related to faecal coliforms (considered here as a surrogate measure of eutrophication via municipal sewage), and both were highest at the most polluted site. We noted no other significant relationships. Thus our data suggest that the parasite communities in these two estuaries were primarily structured by large upstream / downstream ecological gradients in salinity, and secondarily by eutrophication due to pollution by municipal and industrial effluents. Overall, our results highlight the value of coordinated multidisciplinary studies for understanding the factors that shape parasite abundance and community structure.
\end{abstract}

Keywords: parasites, communities, Fundulus heteroclitus, pollution, salinity, pulpmill effluent, municipal sewage

The mummichog Fundulus heteroclitus (L.) is abundant in euryhaline environments on the east coast of North America, ranging from the Gulf of Mexico to the Gulf of St. Lawrence. It is a common prey item for several species of fishes and shorebirds, and is therefore a key component in intertidal food webs (Scott and Scott 1988). Mummichog are relatively long-lived, with a life span of up to five years, and are largely sedentary, feeding mainly on benthic invertebrates within a restricted home range. These traits make mummichog of potential interest as environmental indicators (e.g., see Finley et al. 2009). Between 1993 and 1995, populations of mummichog were extensively studied in two New Brunswick (Canada) rivers putatively experiencing different levels of anthropogenic stress. The Miramichi River received secondary treatment effluent from a bleached kraft pulp mill
(BKM), primary treated wastewater from a groundwood mill, effluent from a former wood-preserving plant, and municipal waste. Conversely, the Bouctouche River, located approximately $90 \mathrm{~km}$ south of the Miramichi, was considered comparatively less polluted; however, it was still subject to non-point inputs of fertilizer and pesticides, as well as municipal effluents from the towns of Bouctouche and Sainte-Marie, New Brunswick (Fig. 1). As part of a multidisciplinary effort to contrast the environmental status of the two rivers, a series of coordinated ecotoxicological studies examined a wide range of endpoints in mummichog from two sites in each river, collecting information on levels of individual contaminants in fish tissues, reproductive parameters, measures of immune function, and genetic effects. Mummichog from the site nearest the BKM had elevated tissue levels of chlorophenolic com-

Address for correspondence: C. Blanar, Fluvial Ecosystem Research Section, Aquatic Ecosystem Protection Research Division, Water Science and Technology Directorate, Science and Technology Branch, Saint Lawrence Centre, Environment Canada, 105 McGill, 7th floor, Montréal, Québec H2Y 2E7, Canada. Phone: +1 514496 6243; Fax:+1 514496 7398; E-mail: chris.blanar@gmail.com 
Table 1. Summary of previous studies on fishes in the Miramichi and Bouctouche estuaries, conducted as part of a coordinated multidisciplinary assessment of the status of site MU (Miramichi River).

\begin{tabular}{|c|c|c|c|}
\hline Authority & Sample date & Fish species & Effects reported in MU fish \\
\hline Couillard and Légaré 1994 & Spring 1993 & Mummichog & $\begin{array}{l}\text { Fin erosion, vertebral malformations } \\
\text { Ethoxyresorufin-O-deethylase (EROD) induction }\end{array}$ \\
\hline Leblanc et al. 1997 & Spring 1994 & Mummichog & $\begin{array}{l}\text { Delayed gonadal maturation } \\
\text { Reduced egg size } \\
\text { Increased fecundity and gonadosomatic index (GSI) }\end{array}$ \\
\hline Couillard et al. 1999 & Spring 1994 & $\begin{array}{l}\text { Tomcod } \\
\text { (Microgadus tomcod) }\end{array}$ & $\begin{array}{l}\text { Decreased condition and delayed gonadal maturity } \\
\text { Multifocal granulomatous lesions, associated with increased density and surface } \\
\text { of pigmented macrophage aggregates (PMA) } \\
\text { Vacuolation of pancreatic tissue }\end{array}$ \\
\hline Couillard and Nellis 1999 & Spring 1995 & Mummichog & $\begin{array}{l}\text { Increased concentrations of chlorophenolic compounds, PCBs, DDT, and } \\
\text { dibenzofurans }\end{array}$ \\
\hline Fournier et al. 1998 & Autumn 1995 & Mummichog & $\begin{array}{l}\text { Decreased phagocytic activity in head kidney macrophages } \\
\text { Decreased macrophage oxidative burst response (female fish only) }\end{array}$ \\
\hline Kirchoff et al. 1999 & $\begin{array}{l}\text { Spring } 1994 \\
\text { Autumn } 1995\end{array}$ & Mummichog & $\begin{array}{l}\text { Alteration of allelic frequencies at } E S T-3 * \text { (esterase) locus } \\
\text { Altered pelvic fin ray counts and fin asymmetry }\end{array}$ \\
\hline
\end{tabular}

pounds, PCBs, DDT, and dibenzofurans; fish from this site also experienced a wide range of physiological disturbances, including signs of generalized stress, reproductive effects, altered immune function, and genetic effects (see Table 1; Couillard and Légaré 1994, Leblanc et al. 1997, Fournier et al. 1998, Couillard et al. 1999, Couillard and Nellis 1999, Kirchoff et al. 1999).

The scope of this earlier work meant that significant information was readily available on both the mummichog (e.g., immune function, condition) and their immediate environment (e.g., tissue contaminant burdens) for all four study sites. This provided a unique opportunity to assess the relative importance of human activities, host condition, and natural environmental variation on parasite abundance and community structure in mummichog that were collected from the same sites at the same time. Although several recent field studies have attempted to assess the interactions of human activities and environmental factors on parasite abundance and infracommunity structure in the same host population, the range of factors considered is often quite restricted. For example, the degree of anthropogenic disturbance is often poorly understood; sample sites are often described as "polluted" or "impacted", with little effort to identify and quantify the contaminants or stressors present (Blanar et al. 2009). Similarly, fish hosts are often assumed to be "stressed" at these sites, but evidence of the degree of actual stress experienced by the host is rarely presented. Fish parasite abundance, and infracommunity composition and structure, have been shown to be affected by a number of factors including host ecology and physiology, environmental factors, and anthropogenic stressors (Marcogliese 2005, Thomas et al. 2005, Poulin 2007). Increases in parasitism can result from stress-related immune suppression, or from ecological changes that increase intermediate host abundance or otherwise favour parasite transmission (Khan and Thulin 1991, MacKenzie et al. 1995). Conversely, decreases in parasitism can result from direct toxicity to parasites, or ecological changes that decrease intermediate host abundance (MacKenzie 1999, Pietrock and Marcogliese 2003, Marcogliese 2005).

To assess the relative importance of human activities, host condition, and natural environmental variation on parasite abundance and community structure, additional mummichog were collected from each site concurrently with the coordinated ecotoxicological studies, and examined for parasites. The first objective of the present study was to identify the parasite fauna and characterize infracommunity and component community diversity and evenness at the four study sites. The second objective was to assess the effects of the previously published factors listed above on the abundance of individual parasite species, and on overall parasite community composition and structure. Specifically, we contrasted the abundance of individual parasite species and parasite infracommunity and component community composition among the four sites, and attempted to relate the observed differences to host factors (size, condition, immune function, tissue pollutant levels), and environmental factors (faecal coliform counts, salinity, temperature).

\section{MATERIALS AND METHODS}

Adult mummichog (Fundulus heteroclitus) were sampled from four sites in the Miramichi and Bouctouche rivers (Fig. 1). Site MU (Miramichi upper estuary) was located approximately $4 \mathrm{~km}$ downstream of the BKM, near the town of Miramichi, New Brunswick. Site ML (Miramichi lower estuary) was located further downstream, well within the estuarine section of the river, approximately $39 \mathrm{~km}$ from the BKM. Site BU (Bouctouche upper estuary) was immediately upstream of the town of Sainte-Marie, while site BL (Bouctouche lower estuary) was located in the estuarine section of the river, approximately $20 \mathrm{~km}$ downstream. Sites MU and BU were situated near the upstream distribution limit for mummichog in their respective watersheds.

Fish were captured from subtidal sites in late May and early June 1995 using minnow traps baited with capelin (Mallotus villosus). Traps were deployed for two tidal cycles (approximately 
20 hours) and retrieved the following day. Fish were killed by a blow to the head, weighed (wet weight $\pm 1 \mathrm{~g}$ ), measured (total length $\pm 1 \mathrm{~mm}$ ), and frozen at $-20^{\circ} \mathrm{C}$ until processing. Fish were gradually thawed and examined for parasites following the process described by Marcogliese (http://www.biology.ualberta. $\mathrm{ca} /$ parasites/ParSec/texten/modstic1.htm). The external surface was rinsed, and the rinse examined for ectoparasites using a stereomicroscope. Eyes were removed and individually examined. Gill arches were examined separately and pressed between glass plates. The surface of the body and fins were inspected, the viscera were removed and internal organs (heart, liver, spleen, swim bladder, gall bladder, digestive tract, gonads, muscle tissue) individually examined for endoparasites while pressed between glass plates. All helminths were fixed and stored in $70 \%$ ethanol pending identification; platyhelminths and acanthocephalans were identified after being stained in acetocarmine and mounted in Permount. Nematodes were fixed and stored in a mixture of $5 \%$ glycerol and $70 \%$ ethanol, and identified after approximately 10 days clearing in glycerol. Identification of parasite species was based on standard keys (Beverley-Burton 1984, Schmidt 1986, Gibson 1996, Hoffman 1999). Parasite prevalence (percentage of fish infected with a given parasite species), abundance (number of parasites of a given species divided by the total number of fish examined), and infracommunity and component community richness were calculated as per Bush et al. (1997). Monogeneans were not enumerated, so it was not possible to calculate their abundance; only prevalence was recorded. Component community structure was further characterized by calculating Pielou's evenness $\left(J^{\prime}\right)$, using the DIVERSE procedure in PRIMER 6.1.13 (for specific formulae see Clarke and Warwick 2001). Pielou's $J$ ' was chosen as an univariate measure of evenness as it is commonly used in community ecology, and is easily interpreted: higher values of $J$ 'indicate that parasite abundances are similar among species and samples, with less numerical dominance by individual species. Its use is particularly recommended in situations where the community is completely censused (see Magurran 1988, Clarke and Warwick 2001).

Whole-body contaminant data for mummichog were obtained from a previously published study (Couillard and Nellis 1999). The tissues analyzed were from fish of the same species, collected from the same four sites, on the same dates. Data for four broad classes of pollutant (total PCDDs and PCDFs, total chlorophenols, total PCBs, and total organic pesticides) were reduced using principal components analysis (PCA) after normalization (see Clarke and Warwick 2001), and the first and second PC axis scores were retained. Similarly, a previous study by Fournier et al. (1998) yielded information on mummichog immune parameters (phagocytic activity and oxidative burst response in head kidney macrophages). These data were normalized and reduced using PCA, and the first PC axis score retained. Faecal coliform levels, salinity, and temperature for each site were estimated based on data collected throughout the Miramichi and Bouctouche estuaries during May and June 1995 by Environment Canada's Marine Water Quality Monitoring program. Thus, data describing a wide range of host and environmental factors were available, and these are summarized in Table 2.

Sex ratios did not differ significantly from 1:1 at any site (chisquare, $p=0.406$; SYSTAT 2004), nor was sex a significant factor in any of the following statistical procedures. Therefore all

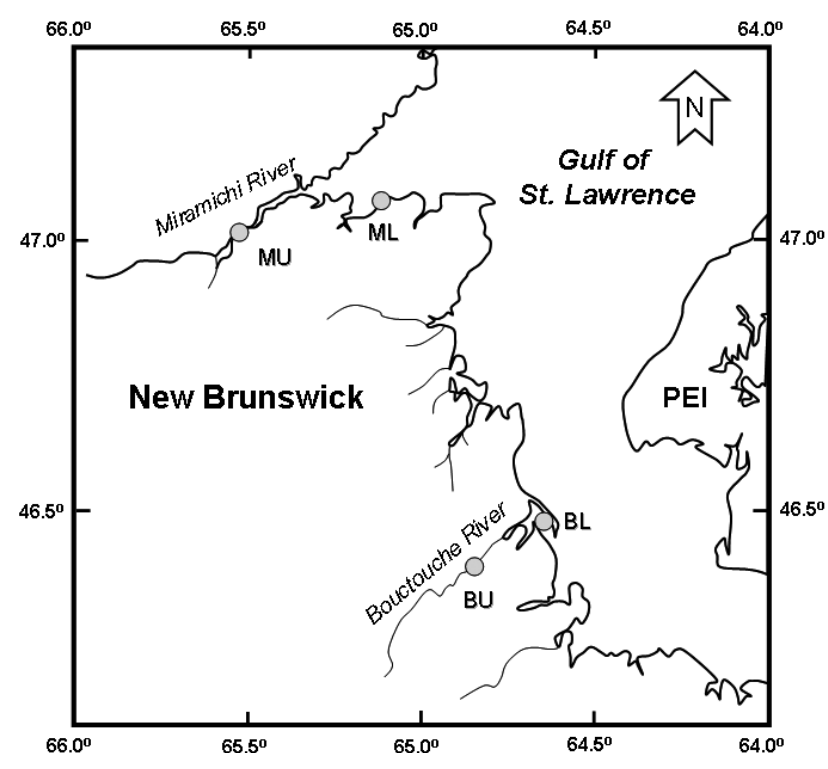

Fig. 1. Map of sample sites. Abbreviations: MU - Miramichi upper estuary; ML - Miramichi lower estuary; BU - Bouctouche upper estuary; BL - Bouctouche lower estuary.

tests were performed on pooled data for both males and females. For all parametric tests, assumptions of normality were verified using Kolmogorov-Smirnov, and homogeneity of variances were verified using Levene's test (SYSTAT 2004). Differences in fish condition among sites were estimated using Fulton's K $\left(\mathrm{K}=\right.$ wet weight $/$ total length $\left.{ }^{3}\right)$. Fish length and parasite infracommunity richness were compared among sites using ANOVA followed by a Tukey post-hoc test (SYSTAT 2004). Overall differences in parasite infracommunity composition were assessed using PRIMER-E (Clarke and Warwick 2001). First, an infracommunity similarity matrix was established using Bray-Curtis similarity indices on unstandardized, square-root transformed data. Sites were characterized based on watershed (i.e., Miramichi or Bouctouche) and location within the watershed (i.e., upper or lower estuarine habitat). The influences of watershed and habitat on parasite community composition were tested using the PRIMER-E ANOSIM procedure. The relative contribution of individual species to differences between watersheds and between habitats was determined using the SIMPER procedure. Nonmetric multidimensional scaling (NMDS in PRIMER 6.1.13) was used to graphically represent differences in infracommunity structure among fish from each site; the similarity matrix was used to generate a two-dimensional graphical solution that arranges the infracommunities such that the distance between two points is inversely proportional to their similarity. The relative importance of individual host and environmental factors on parasite community composition was indicated by overlaying vectors for these factors (PCA on normalized data) on the NMDS plot. Lastly, the effects of host factors (length, condition, immune function, tissue contaminant levels) and environmental factors (faecal coliform counts, salinity, temperature) on parasite compound community richness, mean infracommunity richness, and mean evenness were assessed using linear least-squares regression (SYSTAT 2004). 


\section{RESULTS}

A total of 71 mummichog were captured. Total length varied among sites, with Miramichi fish being consistently longer (ANOVA, $\mathrm{F}=16.02,3 \mathrm{df}, \mathrm{p}<0.01$ ) and having the highest condition (K) (ANOVA, $F=10.12,3 \mathrm{df}$, $\mathrm{p}<0.01$; Table 3 ). Eighteen metazoan parasite species, 10 of these in the larval stage (indicated by an asterisk), were identified (Table 3), including three monogeneans (Gyrodactylus sp., Fundulotrema sp., Salsuginus sp.), two arthropods (Ergasilus manicatus Wilson, 1911, Argulus funduli Krøyer, 1863), five digeneans (Ascocotyle sp.", Ornithodiplostomum sp.., Posthodiplostomum sp.", Diplostomum sp.*, Hemiurus levinseni Odhner, 1905), one cestode (Proteocephalus filicollis (Rudolphi, 1802)), five nematodes (Contracaecum sp. ${ }^{*}$ Hysterothylacium sp., Cosmocephalus obvelatus (Creplin, 1825)*, Paracuaria adunca (Creplin, 1846)*, Eustrongyloides sp.*), and two acanthocephalans (Neoechinorhynchus rutili (Müller, 1780), Corynosoma sp.*). Four of these (Salsuginus sp., Diplostomum sp., Eustrongyloides sp., and Corynosoma sp.) were so rarely found ( $<5 \%$ of mummichog infected) as to be considered accidental infections, and were omitted from further analysis. Prevalence and abundance data for the remaining species are presented in Table 3. Parasite compound community species richness varied among sites, with MU, ML, BU, and BL having 12, 14, 12 , and 9 species respectively. Mean infracommunity species richness was significantly higher in the Miramichi (ANOVA, $\mathrm{F}=37.16,1 \mathrm{df}, \mathrm{p}<0.01$ ), and was consistently higher in the upper estuarine sections at both locations (Fig. 2; ANOVA, $\mathrm{F}=10.53,1 \mathrm{df}, \mathrm{p}<0.01$ ). However, Pielou's evenness $\left(J^{\prime}\right)$ was highly variable among samples, and no significant among-site differences were found (ANOVA, $\mathrm{F}=0.628,1 \mathrm{df}, \mathrm{p}=0.431$ ). Ascocotyle $\mathrm{sp}$. was by far the most abundant species (mean 1144.1, range 241.7-2291.3) and was found in every fish sampled. Ornithodiplostomum sp., Posthodiplostomum sp., and Proteocephalus filicollis were also abundant at all four sites.

Multidimensional scaling (NMDS stress 0.08; Fig. 3A) and ANOSIM of the Bray Curtis similarities among sites revealed two broad patterns: first, upper and lower estuarine sites clustered separately, indicating clear differences in parasite infracommunity composition between brackish and marine habitats (ANOSIM R $=0.474$, $\mathrm{p}=0.001)$; and second, there was a less-pronounced clustering of infracommunities by river of origin (ANOSIM $\mathrm{R}=0.307, \mathrm{p}=0.001$ ). A subsequent SIMPER analysis indicated that infracommunity similarity between watersheds (i.e., Miramichi vs. Bouctouche) and between upper and lower estuarine sites was primarily determined by the relative abundance of five species: Ascocotyle sp., Posthodiplostomum sp., Ornithodiplostomum sp., N. rutili, and Contracaecum sp. Of these, Ascocotyle sp. contributed $57.7 \%$ of the average similarity, with the remaining species contributing $9.4 \%, 8.9 \%, 5.9 \%$, and $4.7 \%$ respec-

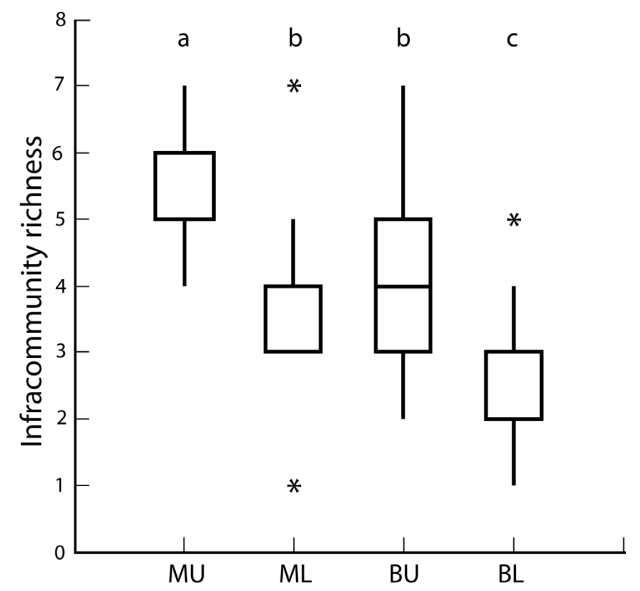

Fig. 2. Box plot of parasite infracommunity richness (mean species richness in individual host fish) at the four study sites. Whiskers indicate minimum and maximum values, while the bottom and top of the boxes represent the lower and upper quartiles respectively; outliers are indicated with asterisks. Letters denote significant differences among sites. Abbreviations: MU - Miramichi upper estuary; ML - Miramichi lower estuary; BU - Bouctouche upper estuary; BL - Bouctouche lower estuary.

tively. Overall, Ascocotyle sp. and Posthodiplostomum sp. were more abundant in the upper estuarine sites. Ornithodiplostomum sp. and N. rutili were more abundant in the Miramichi watershed, whereas Contracaecum sp. and Posthodiplostomum sp. tended to be more abundant in the Bouctouche watershed (Fig. 3A).

Tissue contaminant data (Table 2) were reduced using PCA, with the first two principal component axes accounting for $98.9 \%$ and $1.0 \%$ of the variation respectively. Eigenvector values for the different types of contaminants indicated that the first axis, PCA1, was primarily driven by tissue PCDD and PCDF, while the second axis, PCA2, was largely driven by pesticides. For host immune parameters (Table 2), only the first principal component axis, accounting for $78.6 \%$ of the variation, was retained. Data collected by Environment Canada during the study period (i.e., averaged for the months of May and June) indicated that faecal coliform counts were more elevated in the upper estuarine sections of both watersheds, being highest at the MU site. Salinity and temperature ranged from 11.3 to $24.1 \%$ and 18.3 to $20.2^{\circ} \mathrm{C}$ respectively, with the MU site being the warmest (albeit by less than $2^{\circ} \mathrm{C}$ ) and least saline, whereas the BL site was coldest and most saline (Table 2; Fig. 3 B).

Few significant effects of host and environmental factors on parasite infracommunity and component community diversity and evenness were noted. Salinity and faecal coliforms had significant effects on mean infracommunity diversity. Mean infracommunity diversity decreased significantly in sites with elevated salin- 

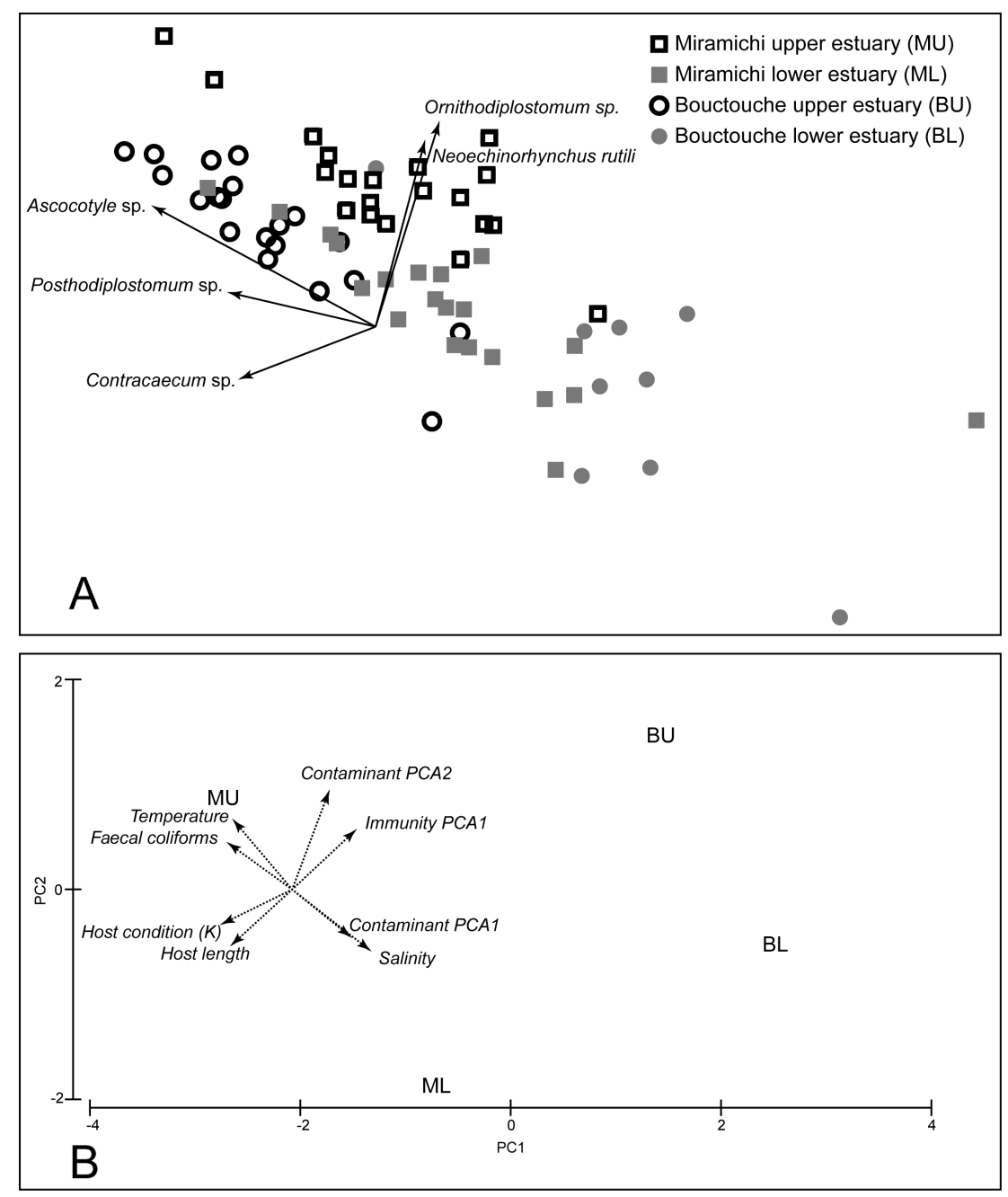

Fig. 3. A - Nonmetric multidimensional Scaling (NMDS, stress $=0.08$ ) plot of mummichog parasite infracommunity composition. Infracommunities from individual fish are labelled by sample site. The distance between points is inversely proportional to infracommunity similarity, based on a Bray-Curtis similarity matrix calculated from unstandardized, square-root transformed data. Vectors indicate the relative strength and direction of influence of the most abundant parasite species on the NMDS plot. B - Principal Components Analysis (PCA) plot of normalized environmental and host factor data from Table 2, indicating the relative strength of each factor at each site.

ity $\left(r^{2}=0.909, t=-4.477,3 \mathrm{df}, \mathrm{p}=0.046\right)$. Conversely, mummichog from sites with elevated faecal coliform counts had higher infracommunity diversity (regression; $r^{2}=0.913, t=4.573,3 \mathrm{df}, \mathrm{p}=0.045$ ). None of the other factors had significant effects on total parasite species, infracommunity diversity, or species evenness (as Pielou's $J$; all p $>>0.05$ ) (Table 4).

\section{DISCUSSION}

This is the first published account of the parasites of mummichog in this part of the southern Gulf of St. Lawrence. Of the 18 parasites identified, several had not previously been recorded in this host species (Ergasilus manicatus, Ornithodiplostomum sp., Hemiurus levinseni, Hysterothylacium sp., Cosmocephalus obvelatus, and Paracuaria adunca), while one had not previously been recorded in Canada (Ascocotyle sp.) (Margolis and Arthur
1979, McDonald and Margolis 1995, Hoffman 1999, Harris and Vogelbein 2006). Although parasites with direct lifecycles (Monogenea, Arthropoda) were well represented, parasite communities were dominated by species with complex life cycles. Most of these use aquatic birds as the definitive host, including Ornithodiplostomum sp., Posthodiplostomum sp., Ascocotyle sp., Contracaecum sp., P. adunca, and C. obvelatus. The remainder use fish as the definitive hosts, including H. levinseni, Hysterothylacium sp., and Neoechinorhynchus rutili. There were broad differences in community composition between the two rivers. For instance, we found that Ascocotyle sp. and Posthodiplostomum sp. were more abundant in the Bouctouche, whereas Ornithodiplostomum sp. and N. rutili were more abundant in the Miramichi. Mean infracommunity richness was also significantly higher in the Miramichi than in the Bouctouche. 
Table 2. Summary data on tissue contaminant levels (Couillard and Nellis 1999) and immune parameters (Fournier et al. 1998) in mummichog from upper and lower estuarine sites in the Miramichi and Bouctouche Rivers, with data on water chemistry (salinity, temperature) and quality (using faecal coliform counts as a surrogate). Data on tissue contaminant levels and immune function were reduced using principal components analysis (PCA). Water chemistry and quality parameters are means of data collected in May and June 1995 by Environment Canada's Marine Water Quality Monitoring program.

\begin{tabular}{|c|c|c|c|c|c|}
\hline & & \multicolumn{2}{|c|}{ Miramichi } & \multicolumn{2}{|c|}{ Bouctouche } \\
\hline & & Upper & Lower & Upper & Lower \\
\hline \multicolumn{6}{|l|}{ Contaminant data } \\
\hline$\Sigma$ PCDD/F (as TEQ) & $\mathrm{pg} / \mathrm{g}$ & 13800 & 1900 & 1300 & 1600 \\
\hline$\Sigma$ Chlorophenols & $\mathrm{pg} / \mathrm{g}$ & 10915 & 478 & 640 & 402 \\
\hline$\Sigma \mathrm{PCB}$ & $\mathrm{pg} / \mathrm{g}$ & 7589 & 1120 & 1022 & 1603 \\
\hline$\Sigma$ Pesticides & $\mathrm{pg} / \mathrm{g}$ & 59963 & 13051 & 24009 & 18309 \\
\hline PCA1 & & -2.98 & 1.12 & 0.91 & 0.98 \\
\hline PCA 2 & & 0.01 & 0.22 & 0.04 & -0.27 \\
\hline \multicolumn{6}{|l|}{ Immune parameters } \\
\hline Phagocytic cells & $\%$ & 26 & 34 & 26 & 24 \\
\hline Phagocyte activity & $\%$ & 6 & 10 & 22 & 19 \\
\hline Oxidative burst & $\%$ & 85 & 100 & 48 & 60 \\
\hline PCA1 & & 1.76 & 1.94 & -2.32 & -1.38 \\
\hline \multicolumn{6}{|c|}{ Water chemistry and quality } \\
\hline Faecal coliforms & $(\mathrm{MPN} / 100 \mathrm{ml})^{1}$ & 63 & 37 & 42 & 5 \\
\hline Salinity & PPT & 11.3 & 18.3 & 17.2 & 24.1 \\
\hline Temperature & ${ }^{\circ} \mathrm{C}$ & 20.2 & 18.6 & 19.1 & 18.3 \\
\hline
\end{tabular}

${ }^{1}$ MPN: Most Probable Number
That said, the most significant finding of this study was a pronounced difference in parasite community structure between sites in the upper vs. the lower estuaries, and the abundances of several species (such as Ascocotyle sp. and Posthodiplostomum sp.) were quite different between the two habitats. Ordination techniques, combined with ANOSIM of parasite infracommunity similarity and PCA of the biotic and abiotic factors, revealed that sites were clustered based on their position in the watershed (i.e., upper estuarine vs. lower estuarine). The primary factor driving this similarity was likely salinity, as this was the environmental variable with the most pronounced upstream/downstream gradient in this system. Furthermore, there was a significant negative effect of salinity on parasite infracommunity richness. Taken together, these results suggest that salinity had a strong effect on parasite community composition. Salinity has been shown to have significant influence on parasite community composition in flounder (Platichthys flesus; see Schmidt et al. 2003), eels (Anguilla anguilla; see Jakob et al. 2008), threespine sticklebacks (Gasterosteus aculeatus; see Poulin et al. 2011), and several marine fishes (Zoarces viviparus and four gobiids; see Zander and Reimer 2002). In a comprehensive study of habitat effects on mummichog parasites in brackish marshes, Anderson and Sukhdeo (2010) ranked the biotic and abiotic factors affecting the presence/absence of three common parasites of mummichog in New Jersey tidal marshes, and found that salinity ranked second or third, behind the availability of

Table 3. Fish morphometrics (mean $\pm \mathrm{SD}$ ), parasite community structure, and prevalence $(\mathrm{P})$ and abundance (A) of common parasite species (mean $\pm \mathrm{SD}$ ) in mummichog (Fundulus heteroclitus) from the Miramichi and Bouctouche Rivers. Larval parasites are indicated by an asterisk.

\begin{tabular}{|c|c|c|c|c|c|c|c|c|c|}
\hline & & \multicolumn{4}{|c|}{ Miramichi } & \multicolumn{4}{|c|}{ Bouctouche } \\
\hline & & \multicolumn{2}{|c|}{ Upper estuary $(\mathrm{n}=20)$} & \multicolumn{2}{|c|}{ Lower estuary $(\mathrm{n}=21)$} & \multicolumn{2}{|c|}{ Upper estuary $(\mathrm{n}=20)$} & \multicolumn{2}{|c|}{ Lower estuary $(\mathrm{n}=10)$} \\
\hline \multirow[t]{3}{*}{ Fish } & Length (mm) & \multicolumn{2}{|r|}{$95.2 \pm 6.4$} & \multicolumn{2}{|c|}{$99.6 \pm 8.5$} & \multicolumn{2}{|r|}{$86.6 \pm 6.8$} & \multicolumn{2}{|r|}{$83.5 \pm 8.5$} \\
\hline & Weight (g) & \multicolumn{2}{|r|}{$11.8 \pm 2.9$} & \multicolumn{2}{|c|}{$13.2 \pm 3.9$} & \multicolumn{2}{|r|}{$7.5 \pm 2.8$} & \multicolumn{2}{|r|}{$6.3 \pm 2.2$} \\
\hline & Condition (K) & \multicolumn{2}{|r|}{$1.34 \pm 0.15$} & \multicolumn{2}{|c|}{$1.30 \pm 0.17$} & \multicolumn{2}{|r|}{$1.1 \pm 0.2$} & \multicolumn{2}{|r|}{$1.1 \pm 0.1$} \\
\hline \multirow[t]{3}{*}{ Parasite community } & Total species & \multicolumn{2}{|r|}{12} & \multicolumn{2}{|r|}{14} & \multicolumn{2}{|r|}{12} & \multicolumn{2}{|r|}{9} \\
\hline & Mean infracommunity richness & \multicolumn{2}{|r|}{$5.7 \pm 1.1$} & \multicolumn{2}{|r|}{$4.8 \pm 1.6$} & \multicolumn{2}{|r|}{$4.1 \pm 1.6$} & \multicolumn{2}{|r|}{$2.7 \pm 1.7$} \\
\hline & Pielou's evenness $\left(J^{\prime} \times 10^{-2}\right)$ & \multicolumn{2}{|r|}{9.2} & \multicolumn{2}{|r|}{7.6} & \multicolumn{2}{|r|}{4.9} & \multicolumn{2}{|r|}{11.8} \\
\hline Parasite taxa & & $\mathrm{P}$ & A & $\mathrm{P}$ & A & $\mathrm{P}$ & A & $\mathrm{P}$ & A \\
\hline & & $\%$ & No./fish & $\%$ & No./fish & $\%$ & No./fish & $\%$ & No./fish \\
\hline Monogenea & Gyrodactylus sp. & 100 & na & 81 & na & 85 & na & 90 & na \\
\hline & Fundulotrema sp. & 95 & na & 52 & na & 85 & na & 60 & na \\
\hline Arthropoda & Ergasilus manicatus & 0 & 0 & 14 & $0.2 \pm 0.5$ & 35 & $1.2 \pm 2.7$ & 44 & $1.1 \pm 1.6$ \\
\hline & Argulus funduli & 60 & $2.4 \pm 3.6$ & 19 & $0.3 \pm 0.8$ & 20 & $0.3 \pm 0.7$ & 22 & $0.2 \pm 0.4$ \\
\hline Digenea & Ornithodiplostomum sp.* & 100 & $22.0 \pm 25.4$ & 100 & $2.6 \pm 1.6$ & 100 & $7.5 \pm 2.0$ & 63 & $7.1 \pm 13.1$ \\
\hline & Posthodiplostomum sp.* & 95 & $6.9 \pm 2.4$ & 86 & $9.2 \pm 16.5$ & 80 & $22.7 \pm 0.7$ & 22 & $0.6 \pm 0.3$ \\
\hline & Hemiurus levinseni & 40 & $1.0 \pm 1.6$ & 5 & $0.1 \pm 0.2$ & 0 & 0 & 11 & $1.8 \pm 5.1$ \\
\hline & Ascocotyle sp.* & 100 & $1375.8 \pm 1579.5$ & 100 & $670.1 \pm 675.3$ & 100 & $2291.3 \pm 1457.9$ & 100 & $241.7 \pm 318.3$ \\
\hline Cestoda & Proteocephalus filicollis & 45 & $13.3 \pm 45.5$ & 62 & $3.7 \pm 4.5$ & 60 & $3.0 \pm 4.6$ & 11 & $0.2 \pm 0.6$ \\
\hline Nematoda & Contracaecum sp.* & 0 & 0 & 14 & $0.2 \pm 0.5$ & 70 & $5.9 \pm 6.4$ & 0 & 0 \\
\hline & Hysterothylacium sp.* & 5 & $0.1 \pm 0.2$ & 5 & $0.1 \pm 0.2$ & 15 & $0.5 \pm 1.4$ & 0 & 0 \\
\hline & Cosmocephalus obvelatus* & 10 & $0.1 \pm 0.3$ & 10 & $0.2 \pm 0.7$ & 0 & 0 & 0 & 0 \\
\hline & Paracuaria adunca* & 15 & $0.2 \pm 0.5$ & 19 & $0.2 \pm 0.6$ & 15 & $0.7 \pm 1.9$ & 0 & 0 \\
\hline Acanthocephala & Neoechinorhynchus rutili & 100 & $6.5 \pm 5.1$ & 14 & $0.3 \pm 0.8$ & 0 & 0 & 0 & 0 \\
\hline
\end{tabular}


suitable invertebrate intermediate hosts and conductivity. On a larger spatial scale, Thieltges et al. (2010) noted that a strong salinity gradient was associated with pronounced decrease of similarity in parasite communities of three marine fishes in the Baltic Sea. This distance decay was not observed in the North Sea, which did not have a strong salinity gradient. Although there is considerable debate on their relative importance, it is clear that parasite community composition can be affected by a wide range of biotic and abiotic factors (Esch and Fernández 1993, Anderson and Sukhdeo 2010). Taken together, these studies suggest that salinity probably plays a major role in structuring parasite communities in euryhaline environments.

Analyses also indicated that the most important anthropogenic factor affecting parasite community composition and infracommunity richness was faecal coliform counts. Faecal coliform levels are considered indicators of municipal sewage (e.g. see Chambers et al. 1997). MU was the site that was putatively most polluted, receiving effluent from several industrial sites - but it also received sewage from several adjacent municipalities, which likely accounts for the elevated faecal coliform counts at that site. Faecal coliform levels may be considered as a surrogate measure of nutrient enrichment and eutrophication from sewage (deBruyn et al. 2003). Effluent from the pulp mill upstream likely further enhanced eutrophication, which has been observed downstream of mills using the same process (Chambers et al. 2000). It is therefore interesting that this was the site with the highest parasite species richness. Mild to moderate levels of eutrophication have been associated with increases in invertebrate diversity and abundance, as well as increased fish biomass (Hellawell 1986, deBruyn et al. 2003). Similar effects have been noted in parasites at both the population and community levels: of 87 published reports of the effects of sewage on parasites, 57 (or $65.5 \%$ ) noted significant effects, with reports of positive effects on parasite abundance being more common (Blanar et al. 2009). Moderate eutrophication can lead to increased parasite abundance and species richness (Zander and Reimer 2002). It is therefore likely that the increased infracommunity richness noted at site MU was driven by nutrient inputs from the adjacent industries and municipality.

Thus, our data suggest that the parasite communities in both rivers were primarily structured by gradients in salinity present in both rivers, with possible secondary influence by pollution (specifically, anthropogenic eutrophication), mostly at the MU site. The primary focus of the coordinated multidisciplinary project centred on assessing the ecotoxicological impact of the BKM on the Miramichi, and the MU site was placed downstream of the mill for this purpose. Concurrent work by Couillard and Nellis (1999) identified several contaminants in mummichog muscle tissue at the four study sites. Fish from the Miramichi sites, particularly MU, contained
Table 4. Results of regression of host and environmental factors on parasite community composition and structure in mummichog from the Miramichi and Bouctouche Rivers. Significant results are indicated in bold ( $\mathrm{n}=4$ for all tests).

\begin{tabular}{|c|c|c|c|c|}
\hline & Factor & $r^{2}$ & $\mathrm{t}$ & $\mathrm{P}$ \\
\hline \multirow[t]{8}{*}{ Total species } & Host length & 0.672 & 2.023 & 0.180 \\
\hline & Host condition & 0.760 & 2.516 & 0.128 \\
\hline & Contaminant PCA1 & 0.050 & -0.071 & 0.950 \\
\hline & Contaminant PCA2 & 0.129 & -0.544 & 0.641 \\
\hline & Immunity PCA1 & 0.357 & -1.053 & 0.403 \\
\hline & Coliforms & 0.436 & 1.244 & 0.339 \\
\hline & Salinity & 0.353 & -1.045 & 0.406 \\
\hline & Temperature & 0.068 & 0.383 & 0.738 \\
\hline \multirow[t]{8}{*}{$\begin{array}{l}\text { Mean infracom- } \\
\text { munity richness }\end{array}$} & Host length & 0.749 & 2.440 & 0.135 \\
\hline & Host condition & 0.415 & 1.190 & 0.356 \\
\hline & Contaminant PCA1 & 0.474 & -1.342 & 0.312 \\
\hline & Contaminant PCA2 & 0.103 & -0.479 & 0.679 \\
\hline & Immunity PCA1 & 0.546 & -1.552 & 0.261 \\
\hline & Coliforms & 0.913 & 4.573 & 0.045 \\
\hline & Salinity & 0.909 & -4.477 & 0.046 \\
\hline & Temperature & 0.644 & 1.900 & 0.198 \\
\hline \multirow[t]{8}{*}{ Pielou's evenness $\left(J^{\prime}\right)$} & Host length & 0.708 & 2.201 & 0.159 \\
\hline & Host condition & 0.345 & 1.027 & 0.412 \\
\hline & Contaminant PCA1 & 0.035 & -0.270 & 0.813 \\
\hline & Contaminant PCA2 & 0.205 & -0.718 & 0.547 \\
\hline & Immunity PCA1 & 0.030 & -0.250 & 0.826 \\
\hline & Coliforms & 0.261 & -0.840 & 0.489 \\
\hline & Salinity & 0.017 & -0.185 & 0.870 \\
\hline & Temperature & 0.040 & -0.288 & 0.800 \\
\hline
\end{tabular}

polychlorinated dibenzo-p-dioxins and dibenzofurans (PCDD/Fs), chlorophenolic compounds (CPs), and PCBs - contaminants that are typically associated with BKM, wood preservation, and general industrial activity, respectively. Fish from both rivers, especially those that were sampled from sites in the upper estuary, also contained pesticides (mostly DDT, DDE, and their metabolic derivatives). All of these compounds have been reported to influence parasitism levels in aquatic animals, although the size and direction of the reported effects vary. For example, a meta-analysis by Blanar et al. (2009) found that fish exposed to pulp-mill effluents or PCBs tended to have lower abundances of digeneans. A similar analysis by Vidal-Martínez et al. (2010) noted a predominance of negative effects of pesticides, PCBs, and pulp-mill effluents on digeneans, nematodes, cestodes, and crustaceans. Conversely, both meta-analyses found that eutrophication led to increased abundances in almost all parasite taxa. In this context, it is interesting to consider that although previously published studies noted toxic effects in host fish at this site (see Table 1), we observed no effects of host tissue contaminant levels on parasite community composition or structure. This suggests that -at least from the parasites' perspective- the effects of general eutrophication are more significant than toxic effects in this system.

It is possible that some of the rarer parasite taxa may have been under-represented in this study because of 
the relatively low sample sizes used, particularly at site BL where only ten fish were sampled. A commonly-cited "rule of thumb" in parasitology is to sample 30 hosts per site, the number required to detect a parasite of $10 \%$ prevalence with a confidence level of 95\% (Post and Millest 1991). However, this benchmark is not universally applicable. Indeed, this number may sometimes be insufficient, particularly in situations where the parasite community features a large number of relatively rare species. Conversely, if the community is composed of a small number of common species, the parasite community may be adequately characterized despite a small sample size. While we acknowledge that our sample sizes may have caused us to miss some of the rarer taxa, we believe that the majority of parasite richness at our sites (including BL) has been adequately represented. Analysis of the species accumulation curves (using PRIMER 6.1.13, based on randomized data) for each site indicated that our data fit asymptotic models and that the asymptote matched the observed number of species at sample sizes of fewer than ten fish (data not shown), suggesting that our sample sizes were sufficient to characterize the majority of parasite richness (Clarke and Warwick 2001, Dove and Cribb 2006).

Parasites have generated considerable interest as potential indicators of environmental disturbance (e.g., see Blanar et al. 2009), but questions regarding their suitability as indicators remain (Kennedy 1997, Vidal-Martinez et al. 2010). It is interesting to note that whereas several toxic responses were observed in mummichog sampled from the putatively most polluted site, this was not the case for their parasites. Although recent meta-analyses suggest that parasites can respond strongly to certain types of pollution at both the population and community level (Lafferty 1997, Blanar et al. 2009, Vidal-Martinez et al. 2010), our results suggest that toxic or pollution responses can be outweighed by natural environmental gradients. This underscores the point, made by several authors, that the choice of parasites as environmental indicators is not universally applicable and must only be made after careful consideration of the types of pollution involved, the parasite community present, as well as key environmental factors such as salinity (MacKenzie 1999, Marcogliese 2005, Blanar et al. 2009, Vidal Martinez et al. 2010). Our results also illustrate the value of including a wide range of natural and anthropogenic variables in ecotoxicology studies. Such data are frequently available from a number of sources, including previously published work, grey literature, and unpublished monitoring data; this type of information is increasingly accessible online. This would allow future studies to more fully characterize habitats - with the caveat that these data should be collected from the same sites and, ideally, during the time period, which was certainly the case in the present study.

Acknowledgements. We thank Bernard Richard of Environment Canada, Moncton, New Brunswick, Canada, for providing water quality data, and Sean Locke of Environment Canada, Montreal, Quebec, Canada, for assisting with the identification of larval digeneans. France Boily participated in fish collections, necropsies, and preliminary parasite identifications. Joanne Guerin assisted with fish necropsies. We also thank Yves de LaFontaine, Vladimír Bukva, and two anonymous reviewers for providing constructive comments that improved the manuscript.

\section{REFERENCES}

Anderson T.K., Sukhdeo M.V.K. 2010: Abiotic versus biotic hierarchies in the assembly of parasite populations. Parasitology 137: 743-754.

Beverley-Burton M. 1984: Monogenea and Turbellaria. In: L. Margolis and Z. Kabata (Eds.), Guide to the Parasites of Fishes of Canada. Part I. Can. Spec. Publ. Fish. Aquat. Sci. 74, pp. 5-209.

Blanar C.A., Munkittrick K.R., Houlahan J., Maclatchy D.L., Marcogliese D.J. 2009: Pollution and parasitism in aquatic animals: a meta-analysis of effect size. Aquat. Toxicol. 93: $18-28$.

Bush A.O., Lafferty K.D., Lotz J.M., Shostak A.W. 1997: Parasitology meets ecology on its own terms: Margolis et al. revisited. J. Parasitol. 83: 575-583.

Chambers P.A., Allard M., Walker S.L., Marsalek J., Lawrence J., Servos M., Busnarda J., Munger K.S., Adare K., Jefferson C., Kent R.A., Wong M.P. 1997: Impacts of municipal wastewater effluents on Canadian waters: A review. Water Qual. Res. J. Can. 32: 659-713.

Chambers P.A., Dale A.R., Scrimgeour G.J., Bothwell M.L. 2000: Nutrient enrichment of northern rivers in response to pulp mill and municipal discharges. J. Aquat. Ecosyst. Stress Recov. 8: 53-66.

Clarke K.R., Warwick R.M. 2001: Change in Marine Communities: an Approach to Statistical Analysis and Interpretation. 2nd Ed. PRIMER-E, Plymouth, UK.

Couillard C.M., Légaré B. 1994: Temporal variations of fin erosions and vertebral malformations in mummichog living downstream from a bleached kraft pulp mill undergoing chlorine dioxide substitution. In: Proceedings of the Second International Conference on Environmental Fate and Effects of Bleached Pulp Mill Effluents. Vancouver, British Columbia, Canada, p. 83.

Couillard C.M., Nellis P. 1999: Organochlorine contaminants in mummichog (Fundulus heteroclitus) living downstream from a bleached-kraft pulp mill in the Miramichi Estuary, New Brunswick, Canada. Environ. Toxicol. Chem. 18: 2545-2556.

Couillard C.M., Williams P.J., Courtenay S.C., Rawn G.P. 1999: Histopathological evaluation of Atlantic tomcod (Microgadus tomcod) collected at estuarine sites receiving pulp and paper mill effluent. Aquat. Toxicol. 44: 263-278. 
deBruyn A.M.H., Marcogliese D.J., Rasmussen J.B. 2003: The role of sewage in a large river food web. Can. J. Fish. Aquat. Sci. 60: 1332-1344.

Dove A.D.M., CRiBB T.H. 2006: Species accumulation curves and their applications in parasite ecology. Trends Parasitol. 22: 568-574.

Esch G.W., Fernández J.C. 1993: A Functional Biology of Parasitism. Chapman and Hall, London, 337 pp.

Finley M.A., Courtenay S.C., Teather K.L., van den Heuvel M.R. 2009: Assessment of northern mummichog (Fundulus heteroclitus macrolepidotus) as an estuarine pollution monitoring species. Water Qual. Res. J. Can. 44: 323-332.

Fournier M., Lacroix A., Voccia, I. Brousseau P. 1998: Phagocytic and metabolic activities of macrophages from mummichog naturally exposed to pulp mill effluents in the Miramichi River. Ecotoxicol. Environ. Saf. 40: 177-183.

Gibson D.I. 1996: Trematoda. In: L. Margolis and Z. Kabata (Eds.), Guide to the Parasites of Fishes of Canada. Part IV. Can. Spec. Publ. Fish. Aquat. Sci. 124, pp. 1-373.

Harris C.E., Vogelbein W.K. 2006: Parasites of mummichog, Fundulus heteroclitus, from the York River, Virginia, U.S.A., with a checklist of parasites of Atlantic coast Fundulus spp. Comp. Parasitol. 73: 72-110.

Hellawell J.M. 1986: Biological Indicators of Freshwater Pollution and Environmental Management. Elsevier, London, $559 \mathrm{pp}$.

Hoffman G.L. 1999: Parasites of North American Freshwater Fishes. 2nd Ed. Cornell University Press, Ithaca, New York, $539 \mathrm{pp}$.

Jakob E., Hanel R., Klimpel S., Zumholz K. 2008: Salinity dependence of parasite infestation in the European eel Anguilla anguilla in northern Germany. ICES J. Mar. Sci. 66: 358-366.

KenNedy C.R. 1997: Freshwater fish parasites and environmental quality: an overview and caution. Parassitologia 39: 249-254.

Khan R.A., Thulin J. 1991: Influence of pollution on parasites of aquatic animals. Adv. Parasitol. 30: 201-238.

Kirchoff S., SÉvigny J.-M., Couillard C.M. 1999: Genetic and meristic variation in the mummichog Fundulus heteroclitus, living in polluted and reference estuaries. Mar. Environ. Res. 47: 261-283.

LAFFERTY K. 1997: Environmental parasitology: what can parasites tell us about human impacts on the environment? Parasitol. Today 13: 251-255.

Leblanc J., Coulllard C.M., Brêthes J.-C.F. 1997: Modifications of the reproductive period in mummichog (Fundulus heteroclitus) living downstream from a bleached kraft pulp mill in the Miramichi Estuary, New Brunswick, Canada. Can. J. Fish. Aquat. Sci. 54: 2564-2573.
MacKenzie K., Williams H.H., Williams B., McVicar A.H., Siddall R. 1995: Parasites as indicators of water quality and the potential use of helminth transmission in marine pollution studies. Adv. Parasitol. 35: 85-144.

MacKenzie K. 1999: Parasites as pollution indicators in marine ecosystems: a proposed early warning system. Mar. Pollut. Bull. 38: 955-959.

Magurran A.E. 1988. Ecological Diversity and its Measurement. Princeton University Press, Princeton, New Jersey, 179 pp.

Marcogliese D.J. 2005: Parasites of the superorganism: are they indicators of ecosystem health? Int. J. Parasitol. 35: 705-716.

Margolis L., Arthur J.R. 1979: Synopsis of the parasites of fishes of Canada. Bull. Fish. Res. Board Can. 199: 1-269.

McDonald T.E., Margolis L. 1995: Synopsis of the parasites of fishes of Canada: Supplement (1978-1993). Can. Spec. Publ. Fish. Aquat. Sci. 122: 1-265.

Pietrock M., Marcogliese D.J. 2003: Free-living endohelminth stages: at the mercy of environmental conditions. Trends Parasitol. 19: 293-299.

Post R.J., Millest A.L. 1991: Sample size in parasitological and vector surveys. Parasitol. Today 7: 141.

Poulin R. 2007: Evolutionary Ecology of Parasites. 2nd Ed. Princeton University Press, Princeton, New Jersey, 332 pp.

Poulin R., Blanar C.A., Thieltges D.W., Marcogliese D.J. 2011: The biogeography of parasitism in sticklebacks: distance, habitat differences and the similarity in parasite occurrence and abundance. Ecography 34: 540-551.

Schmidt G.D. 1986: Handbook of Tapeworm Identification. CRC Press, Boca Raton, Florida, 688 pp.

Schmidt V., Zander S., Körting W., Steinhagen D. 2003: Parasites of the flounder Platichthys flesus (L.) from the German Bight, North Sea, and their potential use in ecosystem monitoring. Helgol. Mar. Res. 57: 236-251.

Sсотт M.G., Sсотт W.B. 1988: Atlantic Fishes of Canada. University of Toronto Press, Toronto, $730 \mathrm{pp}$.

SYSTAT Software, Inc. 2004: SYSTAT 11: Statistics I, II, III. SYSTAT Software, Inc. Richmond, CA.

Thieltges D.W., Dolch T., Krakau M., Poulin R. 2010: Salinity gradient shapes distance decay of similarity among parasite communities in three marine fishes. J. Fish Biol. 76: 1806-1814.

Thomas F., Renaud F., Guégan J.-F. 2005: Parasitism and Ecosystems. Oxford University Press, New York, 221 pp.

Vidal-Martinez V.M., Pech D., Sures B., Purucker S.T., PouLIN R. 2010: Can parasites really reveal environmental impact? Trends Parasitol. 26: 44-51.

Zander C.D., Reimer L.W. 2002: Parasitism at the ecosystem level in the Baltic Sea. Parasitology 124: S119-S135.

Zar J.H. 1996: Biostatistical Analysis. 3rd Ed. Prentice Hall, New Jersey, 662 pp.

Accepted 20 January 2011 